Research Article

\title{
Determination of Total Mercury in Solid Samples by Anodic Stripping Voltammetry
}

\author{
Thuong Thi Kim Nguyen ${ }^{D},{ }^{1}$ Huyen Thu Luu, ${ }^{1}$ Loi Duc Vu, ${ }^{2}$ Thao Thi Ta, \\ and Giang Thi Huong $\mathrm{Le}^{1}$ \\ ${ }^{1}$ Department of Analytical Chemistry, Faculty of Chemistry, VNU University of Science, 19 Le Thanh Tong Street, \\ Hanoi, Vietnam \\ ${ }^{2}$ Institute of Chemistry, Vietnam Academy of Science and Technology, 18 Hoang Quoc Viet, Hanoi, Vietnam
}

Correspondence should be addressed to Thuong Thi Kim Nguyen; kimthuongbibi@gmail.com

Received 27 September 2020; Revised 30 December 2020; Accepted 2 January 2021; Published 12 January 2021

Academic Editor: Ajaya Kumar Singh

Copyright (C) 2021 Thuong Thi Kim Nguyen et al. This is an open access article distributed under the Creative Commons Attribution License, which permits unrestricted use, distribution, and reproduction in any medium, provided the original work is properly cited.

\begin{abstract}
The anodic stripping voltammetry (ASV) was investigated to determine total mercury in solid samples using a gold electrode. The mercury was deposited on the gold electrode in a preconcentration step. The oxidation peak of mercury was irreversible. The optimal conditions of the procedure were found to be as follows: $0.05 \mathrm{~mol} \mathrm{~L}^{-1} \mathrm{HCl}$ solution, deposition potential $-0.5 \mathrm{~V}$ vs. Ag/ $\mathrm{AgCl} / \mathrm{KCls}$, deposition time $40 \mathrm{~s}$, and sweep rate $0.04 \mathrm{~V} \mathrm{~s}^{-1}$. Under the optimal conditions, the peak current showed a linear dependence on $\mathrm{Hg}^{2+}$ concentration in the range from 0.01 to $0.1 \mathrm{mgl}^{-1}$. The detection limit and quantification limit were $4.28 \mu \mathrm{g} \mathrm{L}^{-1}$ and $12.98 \mu \mathrm{g} \mathrm{L}^{-1}$, respectively. The mean recovery and relative standard deviation were $91.2 \%$ and $2.4 \%(n=9)$. The procedure was successfully applied for determining total mercury in samples collected from Hanoi light bulb warehouse-The Rang Dong Light Source and Vacuum Flask JSC. The results were compared with cold vapor atomic absorption spectrometry (CV-AAS).
\end{abstract}

\section{Introduction}

The high-level toxicity of mercury depends on its chemical forms such as the form of methylmercury has more toxicity than the form of elemental mercury [1-3]. When mercury enters the food chains, its concentration deposits and increases in the food change, affecting the life of many animals $[4,5]$. In the past, mercury was used in several applications such as dentistry, industry, and mining. Unlike other heavy metals, $\mathrm{Hg}$ appearance is universal due to its unique physicochemical properties (volatility, long persistence in the atmosphere, solubility in water and lipids, and incorporation in organometallic compounds) and the possibility of transportation in atmosphere with deposition at considerable distances from the sources [6]. The Health Canada organizations warned their high level of contaminants in soil with the purpose of protecting human health and environmental quality according to various land use types such as agricultural and commercial industry is $6.6 \mathrm{mg} \mathrm{kg}^{-1}[7,8]$

The mercury concentrations in the nature environment are low due to the breakdown of minerals in rocks and soils caused by the wind and water [9]. However, the human activities (such as the mining and the combustion of fossil fuel and solid waste) release a large amount of mercury concentration in the environment $[8,10,11]$.

About $54 \%$ of the global mercury emission from anthropogenic sources was contributed by Asian countries in 2000 [12]. In Vietnam, the pollution of mercury has become a serious problem due to many environmental incidents happened in the recent year. One of the most serious problem accidents happened in Vietnam is the burning of the Rang Dong Light Source and Vacuum Flask Joint Stock Company on August 28, 2019. The fire from the accident released about 15.2-27.2 kilograms of mercury into the environment. Therefore, the development of a method for 
determining total mercury in the environmental sample is very necessary.

Many methods have been reported for the determination of mercury such as high chromatography-inductively coupled plasma mass spectrometry (HPLC/ICP-MS) [13, 14], gas chromatography-mass spectrometry (GC/MS) [2, 15], graphite furnace atomic adsorption spectrometry (GF-AAS) $[5,16,17]$, cold vapor atomic absorption spectrometry (CVAAS) $[3,9,18,19]$, cold vapor atomic fluorescence spectrometry (CV-AFS) [4, 20, 21], chemical vapor generation atomic emission spectrometry (CVG-AES) [22], UV-Vis spectrophotometric $[23,24]$, and anodic stripping voltammetry (ASV) [25-36]. Compared to the ASV methods, the HPLC-MS and GC-MS methods require complex sample preparations and the use of toxic organic solvents (e.g., methanol and acetonitrile), and the analytical is also more complex. The advantages of the anodic stripping voltammetry are no prior separation, high selectivity, low cost, and simplicity.

Several electrodes can be used to determine mercury by stripping voltammetry, for instance, glassy carbon electrodes, gold electrodes [25, 27, 31, 37], modified electrode [29, 35, 38-40], and screen-printed carbon electrodes [41]. The gold electrode has high conductivity and ductility. Moreover, the gold electrode exhibits a high affinity for mercury; hence, it improves selectivity of method. Therefore, the gold electrode was used widely to study the electrochemical behaviors and determine mercury in samples [26]. Depending on the analytical methods and types of sample, specific sample preparations are required such as using aqua regia combined with potassium permanganate solution [1], using mixture of strong acids, and using ultrasonication [42]. The solid samples, which were burned at very high temperature from the accident of the Rang Dong Light Source and Vacuum Flask Joint Stock Company, were collected.

In this research, we proposed a new, low cost, high sensitivity and selectivity analytical method for the determination of mercury in the solid samples applying the anodic stripping voltammetry combining with the gold electrode as the working electrode.

\section{Materials and Methods}

2.1. Reagents and Instrumentation. All chemicals were of analytical grade or higher quality.

All solutions were prepared with double distilled water $\left(\mathrm{ddH}_{2} \mathrm{O}\right)$. All reagents were analytically pure. A stock solution of mercury (II) was $1000 \mathrm{ppm}$. The supporting electrolyte was $2 \mathrm{moll}^{-1} \mathrm{HCl}, 37 \%$ (Merck) $\mathrm{HCl}, 98 \%$ (Merck) $\mathrm{H}_{2} \mathrm{SO}_{4}$, and 68\% (Merck) $\mathrm{HNO}_{3}$.

All measurements for determination of mercury were done on the $\mu$ Autolab type III (Netherlands), interfaced to the electrode assembly $663 \mathrm{VA}$ Metrohm (Switzerland), and controlled by software $757 \mathrm{VA}$. The system consists of a working gold electrode $(d=1 \mathrm{~mm}$; purchased from Metrohm), an $\mathrm{AgCl} / \mathrm{Ag} / \mathrm{KCl}$ reference electrode, a counterelectrode, a stirring glassy carbon rod, and high-purity nitrogen.
2.2. Analytical Procedure. A gold electrode was inserted into the cell, and then, $50.0 \mathrm{~mL}$ of the analytical solution containing $0.05 \mathrm{~mol} \mathrm{~L}^{-1} \mathrm{HCl}$ was added. Prior to the voltammograms measurement, the nitrogen flow was passed through the solution for the removal of oxygen. The differential pulse anodic stripping voltammetry was used to determine $\mathrm{Hg}^{2+}$. The accumulation step was carried out under potential of $-0.5 \mathrm{~V}$ (vs. $\mathrm{Ag} / \mathrm{AgCl} / \mathrm{KCl}_{\mathrm{s}}$ ) for 40 seconds, while the analytical solution was being stirred. After that, the stirring was stopped for $5 \mathrm{~s}$, and the differential pulse voltammograms were recorded from -0.5 to $0.7 \mathrm{~V}$. All measurements were carried out at room temperature $\left(25 \pm 1^{\circ} \mathrm{C}\right)$.

2.3. Samples Preparation. The solid samples were collected from the Rang Dong Light Source and Vacuum Flask Joint Stock Company after the burning accidents on August 28, 2019. Stones, gravel, and light were removed the samples. Then, we weighed accurately using an analytical balance with uncertainty $\pm 0.0001 \mathrm{~g}$. The amounts of samples $(0.1-0.5 \mathrm{~g})$ were transferred to the $50 \mathrm{~mL}$ beakers. A $10 \mathrm{~mL}$ of $37 \%(\mathrm{w} / \mathrm{v})$ $\mathrm{HCl}$ acid was added to each sample. After that, the beakers were covered with a watch glass and boiled at $100^{\circ} \mathrm{C}$ in $60 \mathrm{~min}$. After $60 \mathrm{mins}$, the sample was hot filtered using a $0.45 \mu \mathrm{m}$ filter. The obtained solution was transferred into a $50.0 \mathrm{~mL}$ volumetric flask and made up to $50.0 \mathrm{~mL}$ with $\mathrm{ddH}_{2} \mathrm{O}$. The analytical procedure of measurement was described in Section 2.2.

The concentrations of $\mathrm{Hg}^{2+}$ in the solid samples were calculated by the following equation:

$$
C\left(\mathrm{mg} \cdot \mathrm{kg}^{-1}\right)=\frac{C_{\mathrm{ob}}\left(\mathrm{mg} \cdot \mathrm{l}^{-1}\right) \times k \times V(\mathrm{l})}{a(\mathrm{~kg})},
$$

where $C_{\mathrm{ob}}$ is the concentration obtained in solution sample, $V$ is the volume of solution sample, $k$ is the dilution coefficient, and $a$ is the mass of sample.

2.4. Method Evaluation. After optimizing experimental conditions and instrumental parameters, the suitable conditions were selected to determine mercury. The developed method was evaluated through linear range, limit of detection, limit of quantitation, precision, and recovery. The linearity calibration curve was built in standard solutions and spike solid samples from 10 to $100 \mathrm{ppb}$ and 10 to $150 \mathrm{ppb}$, respectively.

The recovery was determined by spiking a known amount of total mercury in the solid sample. Then, this sample was prepared using the sample preparation described in Section 2.3. The concentration of mercury was determined by the standard addition method. The recovery was calculated according to the following equation:

$$
\text { recovery }(\% R)=\frac{\left(C_{f}-C_{i}\right) \times 100 \%}{C_{\mathrm{ad}}},
$$

where $C_{i}$ and $C_{f}$ are the concentrations of mercury found in the sample before addition of standard solution and after addition of standard solution, respectively, and $C_{\mathrm{ad}}$ is the 
concentration of standard mercury added in the solid sample.

2.5. Method Validation. To validate the analytical results of developed method, the same samples were sent to the standard laboratory of Vietnam Academy of Science and Technology. The cold vapor atomic absorption spectrometry (CV-AAS) was used to determine mercury content in solid samples. The samples were digested by the mixture of three acids $\mathrm{HClO}_{4}, \mathrm{HNO}_{3}$, and $\mathrm{H}_{2} \mathrm{SO}_{4}$ in $50 \mathrm{ml}$ quartz volumetric flask. After 30 minutes, the samples were cooled down to the room temperature and reconstituted to $50.0 \mathrm{~mL}$ by $\mathrm{H}_{2} \mathrm{O}$. Automatic mercury analyzer model HG-21 has been used for determining mercury in samples.

To compare results of the anodic stripping voltammetry (AAS) and the cold vapor atomic absorption spectrometry (CV-AAS), we used the paired $T$-test in 1 tail for checking whether or not the significant error between them [43].

The paired $t$ value was calculated:

$$
t_{\mathrm{cal}}=\frac{(\bar{d}) \sqrt{n}}{S_{d}}
$$

in that $\bar{d}$ is the average of the difference between the two results by the following formula:

$$
\bar{d}=\frac{\sum_{i=1}^{n} d_{i}}{n} .
$$

And $S_{d}$ is the standard deviation of the difference and is calculated as follows:

$$
S_{d}=\sqrt{\frac{\sum\left(d_{i}-\bar{d}\right)^{2}}{n-1}} .
$$

\section{Results and Discussion}

3.1. Cyclic Voltammetry. Electrochemical properties of mercury(II) were investigated by cyclic voltammetry method and displayed in Figures 1-3. Figure 1 shows that the voltammograms of mercury(II) were not reversible caused by the $i_{p a}$ to $i_{p c}$ ratio smaller than 1 [44]. The peak current signal appeared in an oxidation zone, which means mercury (II) exhibits oxidative properties. The electrochemical reaction on the surface of working electrode was irreversible, and no reduction peak appeared on the cyclic voltammograms.

To investigate the accumulation behaviors of mercury on the surface of the gold electrode, the cyclic voltammetry was recorded with different deposition time conditions, specifically 0,30 , and 60 seconds at the same deposition potential of $-0.5 \mathrm{~V}$ of $0.1 \mathrm{mgl}^{-1} \mathrm{Hg}^{2+}$ in $0.05 \mathrm{~mol}$. $\mathrm{L}^{-1} \mathrm{HCl}$ solution. Figure 2 shows that the peak current of mercury depended on deposition time. When deposition time increased, the peak current increased, which indicated that mercury had deposition on the electrode surface.

The effect of scan rate on the oxidation peak current $\left(\mathrm{I}_{\mathrm{pa}}\right)$ of $0.1 \mathrm{mgl}^{-1} \mathrm{Hg}^{2+}$ in $0.05 \mathrm{moll}^{-1} \mathrm{HCl}$ solution using gold electrode was investigated in the range from 10 to $1000 \mathrm{mV} \mathrm{s}^{-1}$. Figure 3 indicates that the relationship between

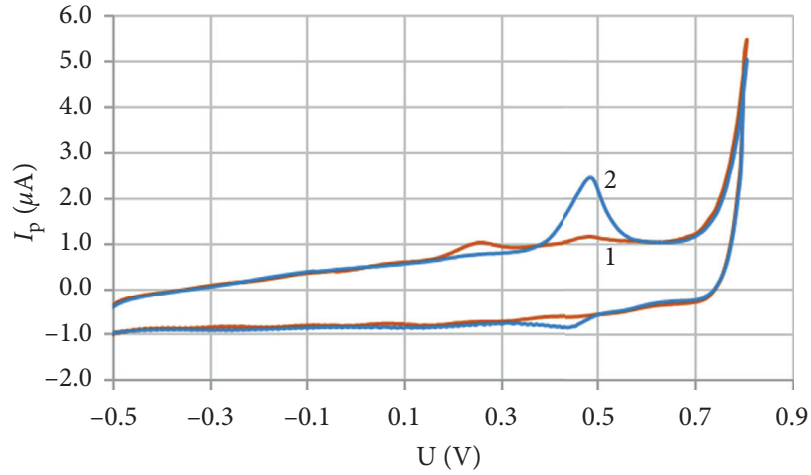

FIgURE 1: Cyclic voltammograms at sweep rate $0.1 \mathrm{~V} \cdot \mathrm{s}^{-1-}$, voltage step $6 \mathrm{mV}$, start potential $-0.5 \mathrm{~V}$, and end potential $0.8 \mathrm{~V}$ : (1) blank $\left(\mathrm{HCl} 0.05 \mathrm{~mol} \mathrm{l}^{-1}\right.$ ); (2) $0.1 \mathrm{mg} \mathrm{L}^{-1} \mathrm{Hg}^{2+}$ in $0.05 \mathrm{~mol} \mathrm{~L}^{-1} \mathrm{HCl}$.

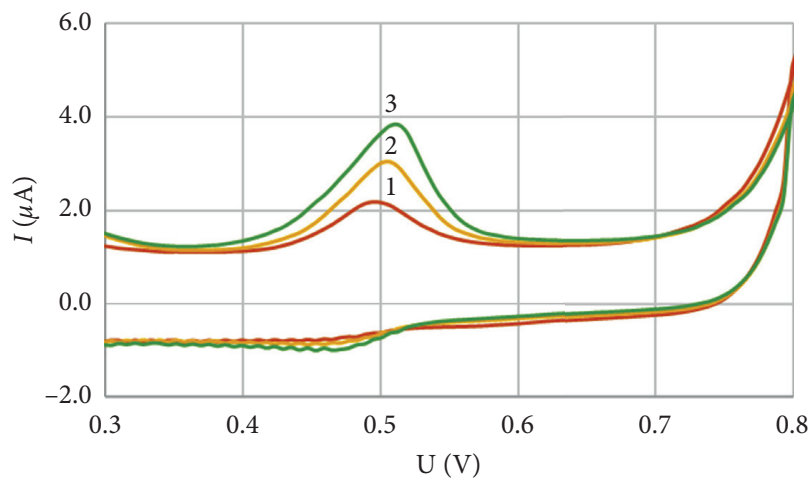

Figure 2: Cyclic voltammograms of $0.1 \mathrm{mgl}^{-1} \mathrm{Hg}^{2+}$ in $\mathrm{HCl}$ $0.05 \mathrm{~mol}^{-1}$, deposition potential $-0.5 \mathrm{~V}$, sweep rate $0.1 \mathrm{~V} \mathrm{~s}^{-1}$, and voltage step $6 \mathrm{mV}$ : (1) deposition time $0 \mathrm{~s}$; (2) deposition time $30 \mathrm{~s}$; (3) deposition time $60 \mathrm{~s}$.

the oxidation peak current and sweep rate in cyclic voltammetry was linearly dependent according to the equation $\log \mathrm{I}_{p}=0.85 \log \mathrm{U}+4.94, R^{2}=0.997 \quad(n=14)$. Theoretically, the slope value of 1.0 suggests the electrochemical reaction occurred on the surface of working electrode, while the value of 0.5 indicated that the current is controlled by semi-infinite diffusion reaction kind in the solution [45]. By fitting the plot of $\log (\mathrm{i})$ as a function of $\log (\nu)$, the slope value for mercury oxidation peak was 0.85 , which indicated that mercury (II) possessed a strong accumulation character onto the gold electrode surface. Therefore, the concentration of mercury was determined by differential pulse anodic stripping voltammetry.

\subsection{Differential Pulse Anodic Stripping Voltammetry}

3.2.1. Choice of Supporting Electrolytes. A high supporting electrolyte concentration is used to minimize the effects of migration to the electrode surface and to reduce the cell resistance which decreases the IR drop. So, the supporting electrolyte is very important factor in voltammetry. To optimize the best medium, some electrolytes such as nitric 


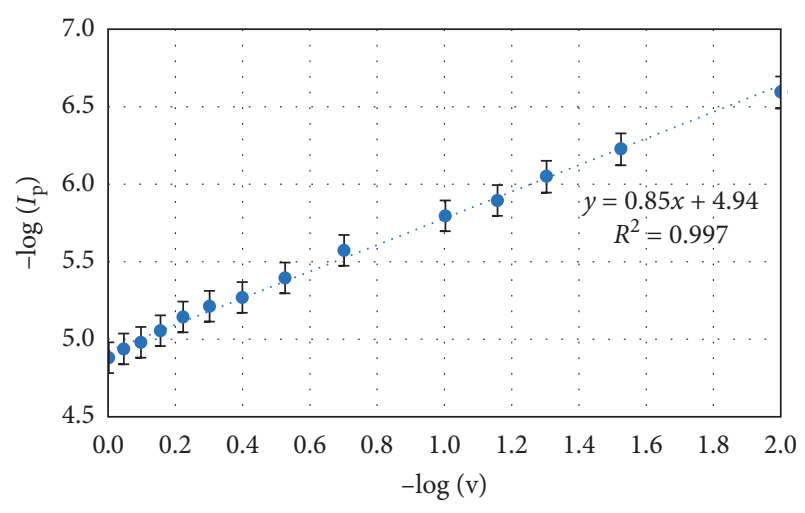

Figure 3: Cyclic voltammetry current $\left(\log I_{\mathrm{p}}\right)$ vs. $\log \mathrm{U}$ plot for $0.1 \mathrm{mg} \mathrm{L}^{-1}$ mercury, deposition potential $-0.5 \mathrm{~V}$, deposition time $30 \mathrm{~s}$, and scan rate from $10 \mathrm{mV} \mathrm{s}^{-1}$ to $1000 \mathrm{mV} \mathrm{s}^{-1}$.

acid, hydrochloric acid, and sulfuric acid were added as measurement solution.

The voltammograms of the acids with $0.2 \mathrm{ppm}$ of $\mathrm{Hg}$ are shown in Figure 4. The results indicated that presence of hydrochloric acid was essential to obtain a good peak current, so $\mathrm{HCl}$ solution was chosen to determine $\mathrm{Hg}^{2+}$.

3.2.2. Effect of Hydrochloric Acid Concentration. The effect of $\mathrm{HCl}$ concentration on the signal of $\mathrm{Hg}^{2+}$ was investigated with the following conditions: the $\mathrm{Hg}^{2+}$ condition $0.1 \mathrm{mgl}^{-1}$, the sweep rate of $0.04 \mathrm{~V} \mathrm{~s}^{-1}$, the pulse amplitude $0.05 \mathrm{~V}$, and the pulse time $0.04 \mathrm{~s}$. The results are presented in Figure 5.

Figure 5 shows that the $\mathrm{HCl}$ concentration affected the current peak of mercury. When $\mathrm{HCl}$ concentration increased from 0.01 to $0.05 \mathrm{moll}^{-1}$, the peak current of mercury also increased. However, the peak current did not increase in the concentration range of $0.05-0.15 \mathrm{moll}^{-1}$. When $\mathrm{HCl}$ concentration was higher than $0.15 \mathrm{moll}^{-1}$, the mercury signal was decreased, which may be caused by the formation of $\mathrm{Hg}^{2+}$ complex with the excess chloride ions $\left(\mathrm{Cl}^{-}\right)$. Therefore, the concentration of $0.05 \mathrm{moll}^{-1} \mathrm{HCl}$ was chosen for all following experiments for determination of mercury.

3.2.3. Effect of the Anodic Stripping Voltammetry Parameters. The sensitivity of the anodic stripping voltammetry depends on both the deposition time and deposition potential. The dependence of the stripping peak current on the deposition potential was also investigated in the range from $-0.9 \mathrm{~V}$ to $0.8 \mathrm{~V}$ for $0.05 \mathrm{mgl}^{-1}$ mercury after preconcentration in $30 \mathrm{~s}$. Figure 6 shows that the peak current was practically depended on the deposition potential. The highest value of peak current could be obtained at a deposition potential of $-0.5 \mathrm{~V}$. After that, the value of peak current decreased when deposition potential increased from $-0.4 \mathrm{~V}$ to $+0.3 \mathrm{~V}$. So, the deposition potential of $-0.5 \mathrm{~V}$ was chosen for the rest of measurements.

Figure 7 indicates that the oxidation peak current increased when deposition time increased from $0 \mathrm{~s}$ to $80 \mathrm{~s}$. After that, the oxidation peak current became independent

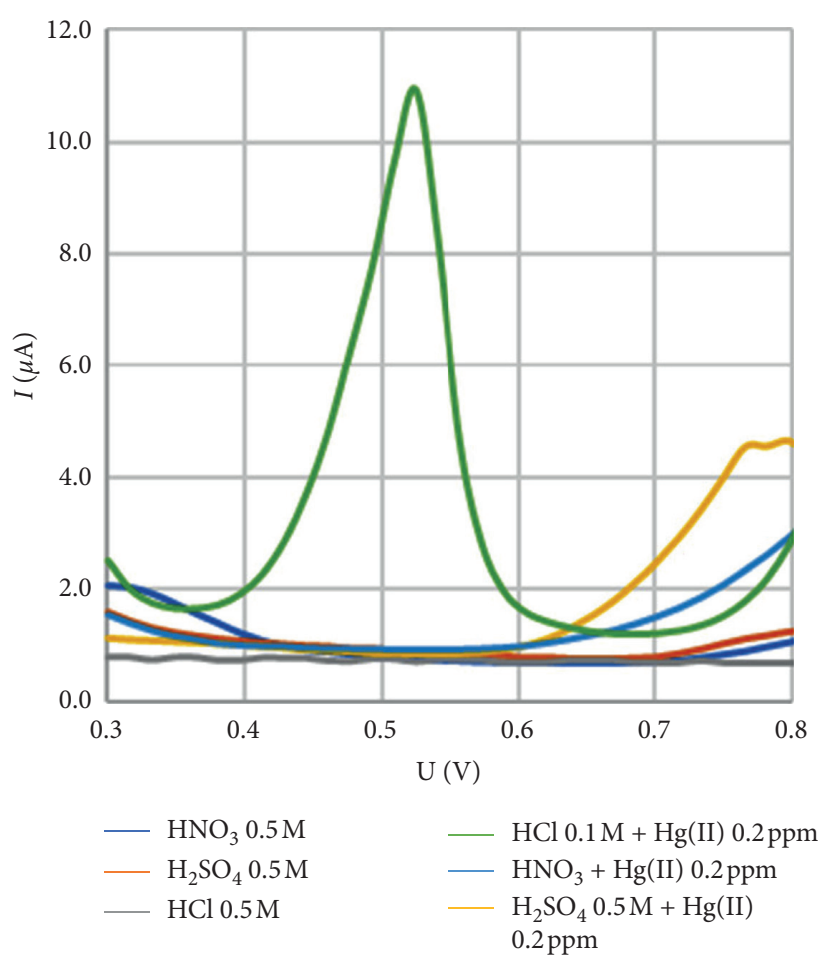

Figure 4: Differential pulse anodic stripping voltammograms of $0.5 \mathrm{moll}^{-1} \mathrm{HCl}, \mathrm{HNO}_{3}$, and $\mathrm{H}_{2} \mathrm{SO}_{4}$ and $0.2 \mathrm{mgl}^{-1} \mathrm{Hg}^{2+}$ in $0.5 \mathrm{moll}^{-1} \mathrm{HCl}, \mathrm{HNO}_{3}$, and $\mathrm{H}_{2} \mathrm{SO}_{4}$, sweep rate $0.04 \mathrm{~V} \mathrm{~s}^{-1}$, pulse amplitude $0.05 \mathrm{~V}$, and pulse time $0.04 \mathrm{~s}$.

with the deposition time, which indicated that the gold electrode surface was completely covered. Therefore, 40 seconds deposition potential was chosen for depositing $0.05 \mathrm{mgl}^{-1} \mathrm{Hg}^{2+}$ on the surface of working electrode.

In the anodic stripping voltammetry using differential pulse technique, the sweep rate affected the peak current. A well-defined peak current was obtained with $0.04 \mathrm{~V} \mathrm{~s}^{-1}$ of the sweep rate.

Accordingly, the optimal differential pulse parameters for the determination of $\mathrm{Hg}^{2+}$ were established as voltage step $4 \mathrm{mV}$, voltage step time $100 \mathrm{~ms}$, sweep rate $40 \mathrm{mV} \mathrm{s}^{-1}$, pulse amplitude $50 \mathrm{mV}$, and pulse time $40 \mathrm{~ms}$. Linear calibration graphs for mercury were obtained from $0.01 \mathrm{mg} \mathrm{l}^{-1}$ to $0.1 \mathrm{mgl}^{-1}$ with regression equation $\mathrm{i}_{\mathrm{pa}}(\mu \mathrm{A})=$ $(0.0017 \pm 0.1601)+(0.0446 \pm 0.0026) \times C_{\mathrm{x}}\left(\mu \mathrm{gL}^{-1}\right)$ and correlation coefficient 0.999 .

3.2.4. Validation of Method. The detection limit (LOD) and quantitation limit (LOQ) were calculated from the linearity calibration curves as $k \times \sigma / \mathrm{S}$ [46] where $k=3$ for LOD and 10 for LOQ, where $\sigma$ stands for standard deviation and $\mathrm{S}$ is the slope of the calibration curve. The detection limit and quantification limit of mercury were found to be as $4.28 \mu \mathrm{gl}^{-1}$ and $12.97 \mu \mathrm{gl}^{-1}$, respectively.

Precision was determined by eleven successive measurements of solution containing $50 \mathrm{~g} \mathrm{l}^{-1} \mathrm{Hg}^{2+}$ in $0.05 \mathrm{moll}^{-1} \mathrm{HCl}$ solution with deposition time of $40 \mathrm{~s}$ at deposition potential $-0.5 \mathrm{~V}$. The relative standard deviation (RSD) was $3.07 \%(n=11)$. The results showed that the RSD 


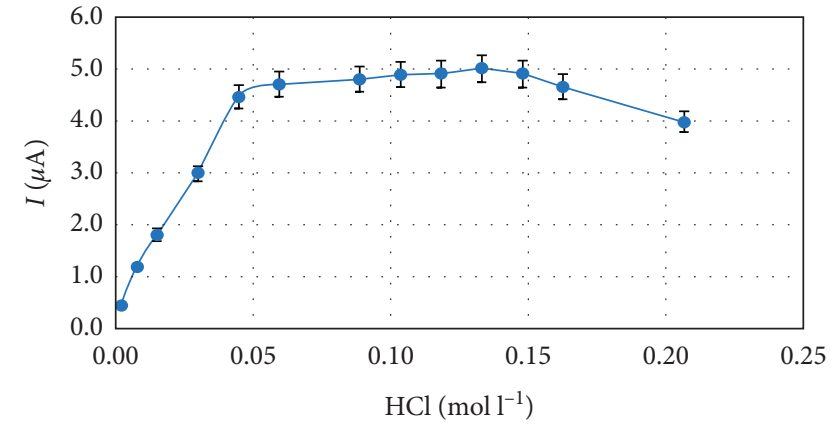

Figure 5: Influence of $\mathrm{HCl}$ concentration on the $I_{\mathrm{p}}$ for $0.1 \mathrm{mg} \mathrm{l}^{-1} \mathrm{Hg}^{2+}$, sweep rate $0.04 \mathrm{~V} \mathrm{~s}^{-1}$, pulse amplitude $0.05 \mathrm{~V}$, and pulse time $0.04 \mathrm{~s}$.

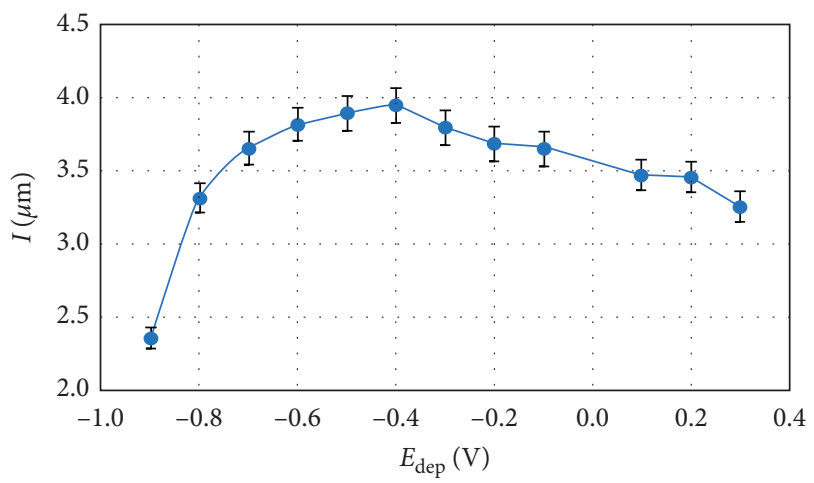

Figure 6: Effect of deposition potential $\left(E_{\mathrm{dep}}\right)$ on the anodic stripping peak current of $0.05 \mathrm{mg} \mathrm{l}^{-1} \mathrm{Hg}^{2+}$ in $0.05 \mathrm{~mol} \mathrm{~L}^{-1} \mathrm{HCl}$, $t_{\mathrm{dep}}=30 \mathrm{~s}$, and sweep rate $0.04 \mathrm{~V} \mathrm{~s}^{-1}$.

(\%) was smaller than 5\%. Therefore, the proposed analytical method has been good repeatability.

To evaluate the precision of the method before we applied to determine mercury in solid samples, two levels of concentration $50 \mu \mathrm{gl}^{-1}$ and $100 \mu \mathrm{gl}^{-1}$ of mercury were added into the solid sample and were analyzed repeatedly nine independent times. The mean recoveries based on nine replicate measurements were found to be $90.51 \pm 1.06 \%$ and $91.53 \pm 0.91 \%$. The relative standard deviation (RSD) was $2.49 \%$ and $2.42 \%$, respectively $(n=9)$. This level of precision was suitable to determine mercury in solid samples at the Rang Dong Light Source and Vacuum Flask Joint Stock Company after burning.

3.2.5. Application. The proposed procedure was successfully applied to determine mercury in solid samples. The quantitative determination of different concentrations of mercury in a spiked solid sample was carried out by using the proposed anodic stripping voltammetry procedure (Figure 8).

The variation in $i_{\mathrm{p}}$ versus mercury concentration $\mathrm{C}$ was represented by the straight-line equation $i_{\mathrm{p}}(\mu \mathrm{A})=$ $(0.1863 \pm 0.1302)+(0.0324 \pm 0.0015) \times \mathrm{C}\left(\mu \mathrm{g} \mathrm{L}^{-1}\right)($ correlation coefficient 0.999 and $n=5$ ). The limits of detection

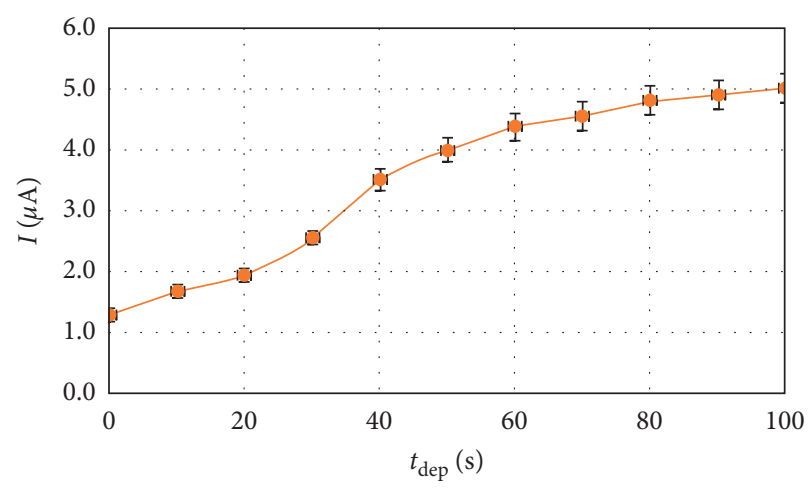

FIgURE 7: Effect of deposition time $\left(t_{\mathrm{dep}}\right)$ on the anodic stripping peak current of $0.05 \mathrm{mgl}^{-1} \mathrm{Hg}^{2+}$ in $0.05 \mathrm{~mol} \mathrm{~L}^{-1} \mathrm{HCl}, E_{\text {dep }}=-0.5 \mathrm{~V}$, and sweep rate $0.04 \mathrm{~V} \mathrm{~s}^{-1}$.

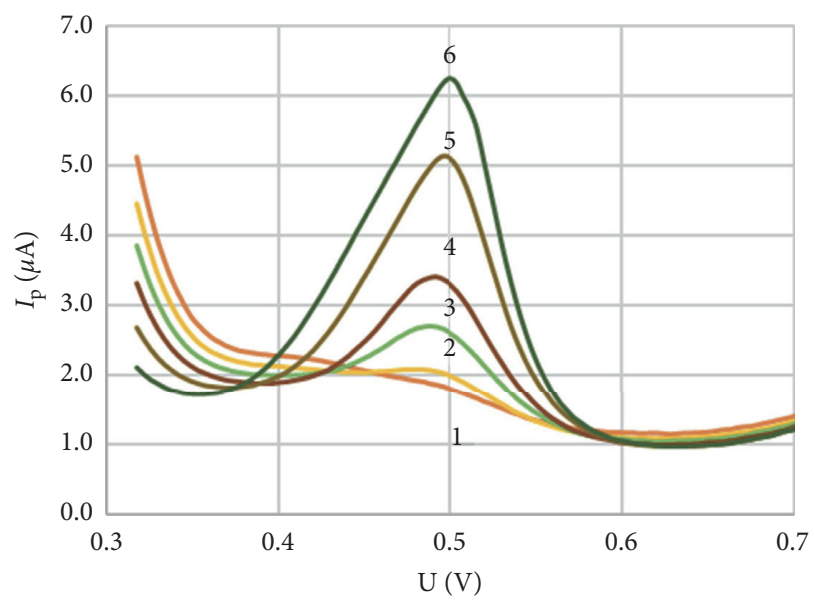

FIGURE 8: Anodic stripping differential pulse voltammograms for increased concentrations of mercury spiked in solid samples: (1) blank; (2) $10 \mu \mathrm{g} \mathrm{L}^{-1}$; (3) $30 \mu \mathrm{g} \mathrm{L}^{-1}$; (4) $50 \mu \mathrm{g} \mathrm{L}{ }^{-1}$; (5) $100 \mu \mathrm{g} \mathrm{L}^{-1}$; (6) $150 \mu \mathrm{g} \mathrm{L}^{-1} ; E_{\mathrm{dep}}=-0.5 \mathrm{~V}, t_{\mathrm{dep}}=40 \mathrm{~s}$, sweep rate $40 \mathrm{mV} \mathrm{s}^{-1}$, pulse amplitude $50 \mathrm{mV}$, pulse time $40 \mathrm{~ms}$, and $0.05 \mathrm{~mol} \mathrm{~L}^{-1} \mathrm{HCl}$.

(LOD) and quantitation (LOQ) of mercury in solid samples were found to be $5.57 \mu \mathrm{g} \mathrm{L}^{-1}$ and $16.88 \mu \mathrm{g} \mathrm{L}^{-1}$, respectively.

The accuracy of the method was verified by using the spiked solid samples. The mean recovery was found to be range from $89.8 \% \pm 1.09$ to $92.6 \% \pm 1.38 \quad(n=9$ replicate measurements). The proposed method was applied to determine total mercury in solid samples collected at an accidental area. The results indicated that mercury was found in all samples collected from Hanoi light bulb warehouse. The highest concentration of mercury was $182.51 \mathrm{mg} \mathrm{kg}^{-1}$. According to the standard of Canadian Health Organization, the allowable $\mathrm{Hg}^{2+}$ content in the soil is $6.6 \mathrm{mg} \mathrm{kg}^{-1}$. The results showed that the concentration of total mercury in the six solid samples collected at the accidental area was higher than the permitted standard of health organization (Table 1). Therefore, we received that each industrial activity has potential risks for the environment.

To validate, the results obtained by the proposed ASV method was compared with those obtained by the CV-AAS 
TABLE 1: Determination of mercury in solid samples by ASV and CV-AAS methods.

\begin{tabular}{lcccc}
\hline Number & Sample & ASV $\left(\mathrm{mg} \mathrm{kg}^{-1}\right)$ & CV-AAS $\left(\mathrm{mg} \mathrm{kg}^{-1}\right)$ & $d$ \\
\hline 1 & CR03 & 92.42 & 97.18 & 4.75 \\
2 & CR23 & 182.51 & 186.82 & 4.31 \\
3 & CR25 & 70.02 & 88.49 & 18.47 \\
4 & CR26 & 18.30 & 21.87 & 3.57 \\
5 & CR27 & 29.23 & 29.32 & 0.09 \\
6 & CR30 & 6.45 & 6.53 & 0.08 \\
7 & CR31 & 3.13 & 2.53 & -0.60 \\
8 & CR33 & 31.82 & 32.15 & 0.32 \\
9 & CR34 & 2.76 & 0.76 & -2.00 \\
& \multicolumn{3}{c}{$S_{d}$} \\
& \multicolumn{3}{c}{ Paired $t$ value } \\
\end{tabular}

method. The results obtained by anodic stripping voltammetry (ASV) and the cold vapor atomic absorption spectrometry (CV-AAS) are summarized in Table 1.

We find that $t_{\text {calculated }}(1.56)$ is less than $t_{\text {table }}$ (1.86) listed in Table 1 for $95 \%$ confidence and 8 degrees of freedom. There is more than a $5 \%$ chance that the two sets of results lie "within experimental error" of each other, so we conclude that the results are not significantly different. However, the ASV has highly sensitive, selective, fast, easy to use, low cost, and less expensive equipment. So, the anodic stripping voltammetry can apply to determine total mercury in the solid sample.

The proposed method was successfully applied to determine $\mathrm{Hg}^{2+}$ content in surface water samples collected from To Lich River without sample preparation. The analytical procedure of measurement was the same as in Section 2.2, but deposition time was $300 \mathrm{~s}$. The $\mathrm{Hg}^{2+}$ content was found in 5 samples collected from To Lich River near Trung Hoa Bridge in May 2020. The $\mathrm{Hg}^{2+}$ content in samples was determined by $1 \mu \mathrm{g} \mathrm{L}^{-1} \mathrm{Hg}^{2+}$ addition standard method. The results obtained for the surface water samples are below the limit values for mercury. The average $\mathrm{Hg}^{2+}$ content in surface water samples was $0.67 \mu \mathrm{g} \mathrm{L}^{-1}$. The results could confirm that the anodic stripping voltammetry can determine the $\mathrm{Hg}^{2+}$ content in water with increasing deposition time.

\section{Conclusion}

The anodic stripping differential pulse voltammetry was developed for the determination of total mercury in solid samples. The electrochemical behaviors of mercury were an irreversible process. The mercury was deposited on the surface of the gold electrode. With the optimum conditions, the proposed method has high selectivity, sensitivity, precision, accuracy, and well repeatability, with high recoveries from $89.8 \%$ to $92.6 \%$. The proposed method successfully applied to the fast determination of mercury in solid samples collected from Hanoi light bulb warehouse-The Rang Dong Light Source and Vacuum Flask JSC. The results are in good agreement with cold vapor atomic absorption spectrometry.

\section{Data Availability}

The data used to support the findings of this study are included within the article.

\section{Conflicts of Interest}

The authors declare that there are no conflicts of interest regarding the publication of this paper.

\section{References}

[1] T. Malehase, A. P. Daso, and J. O. Okonkwo, "Determination of mercury and its fractionation products in samples from legacy use of mercury amalgam in gold processing in Randfontein, South Africa," Emerging Contaminants, vol. 2, no. 3, pp. 157-165, 2016.

[2] S. Mishra, R. M. Tripathi, S. Bhalke, V. K. Shukla, and V. D. Puranik, "Determination of methylmercury and mercury(II) in a marine ecosystem using solid-phase microextraction gas chromatography-mass spectrometry," Analytica Chimica Acta, vol. 551, no. 1-2, pp. 192-198, 2005.

[3] I. Serafimovski, I. Karadjova, T. Stafilov, and J. Cvetković, "Determination of inorganic and methylmercury in fish by cold vapor atomic absorption spectrometry and inductively coupled plasma atomic emission spectrometry," Microchemical Journal, vol. 89, no. 1, pp. 42-47, 2008.

[4] D. G. Da Silva, L. A. Portugal, A. M. Serra, S. L. C. Ferreira, and V. Cerdà, "Determination of mercury in rice by MSFIA and cold vapour atomic fluorescence spectrometry," Food Chemistry, vol. 137, no. 1-4, pp. 159-163, 2013.

[5] A. F. da Silva, B. Welz, and A. J. Curtius, "Noble metals as permanent chemical modifiers for the determination of mercury in environmental reference materials using solid sampling graphite furnace atomic absorption spectrometry and calibration against aqueous standards," Spectrochimica Acta Part B: Atomic Spectroscopy, vol. 57, no. 12, p. 2031, 2002.

[6] N. Lobus, V. Komov, and N. Thanh, "Mercury concentration in ecosystem components in water bodies and streams in Khanh Hoa province (Central Vietnam)," Water Resources, vol. 38, 2011.

[7] K. R. Mahbub, M. M. Bahar, M. Megharaj, and M. Labbate, "Are the existing guideline values adequate to protect soil health from inorganic mercury contamination?" Environment International, vol. 117, pp. 10-15, 2018.

[8] K. R. Mahbub, K. Krishnan, R. Naidu, S. Andrews, and M. Megharaj, "Mercury toxicity to terrestrial biota," Ecological Indicators, vol. 74, pp. 451-462, 2017.

[9] D. P. Torres, V. L. A. Frescura, and A. J. Curtius, "Simple mercury fractionation in biological samples by CV AAS following microwave-assisted acid digestion or TMAH pretreatment," Microchemical Journal, vol. 93, no. 2, pp. 206-210, 2009.

[10] M. Vahter, A. Åkesson, B. Lind, U. Björs, A. Schütz, and M. Berglund, "Longitudinal study of methylmercury and inorganic mercury in blood and urine of pregnant and lactating women, as well as in umbilical cord blood," Environmental Research, vol. 84, no. 2, pp. 186-194, 2000.

[11] F. Xu, S. Farkas, S. Kortbeek et al., "Mercury-induced toxicity of rat cortical neurons is mediated through N-methyl-DAspartate receptors," Molecular Brain, vol. 5, no. 1, p. 30, 2012.

[12] E. G. Pacyna, J. M. Pacyna, F. Steenhuisen, and S. Wilson, "Global anthropogenic mercury emission inventory for 2000," 
Atmospheric Environment, vol. 40, no. 22, pp. 4048-4063, 2006.

[13] S. Le Roux, P. Baker, and A. Crouch, "Determination of mercury in selected polluted sediments using HPLC-ICP-MS in Westbank area, Western Cape, South Africa," South African Journal of Chemistry, vol. 69, pp. 124-131, 2016.

[14] Y. Yuan, Y. Wu, H. Wang et al., "Simultaneous enrichment and determination of cadmium and mercury ions using magnetic PAMAM dendrimers as the adsorbents for magnetic solid phase extraction coupled with high performance liquid chromatography," Journal of Hazardous Materials, vol. 386, p. $121658,2020$.

[15] C. M. Barshick, S.-A. Barshick, P. F. Britt, D. A. Lake, M. A. Vance, and E. B. Walsh, "Development of a technique for the analysis of inorganic mercury salts in soils by gas chromatography/mass spectrometry," International Journal of Mass Spectrometry, vol. 178, no. 1-2, pp. 31-41, 1998.

[16] I. López-García, M. Sánchez-Merlos, and M. HernándezCórdoba, "Determination of mercury in soils and sediments by graphite furnace atomic absorption spectrometry with slurry sampling," Spectrochimica Acta Part B: Atomic Spectroscopy, vol. 52, no. 14, pp. 2085-2092, 1997.

[17] Y. Gao, Z. Shi, Z. Long, P. Wu, C. Zheng, and X. Hou, "Determination and speciation of mercury in environmental and biological samples by analytical atomic spectrometry," Microchemical Journal, vol. 103, pp. 1-14, 2012.

[18] E. Kopysc, K. Pyrzynska, S. Garbos, and E. Bulska, "Determination of mercury by cold-vapor atomic absorption spectrometry with preconcentration on a gold-trap," Analytical Sciences, vol. 16, no. 12, pp. 1309-1312, 2000.

[19] J. Górecki, P. Burmistrz, M. Trzaskowska, B. Sołtys, and J. Gołaś, "Method development and validation for total mercury determination in coke oven gas combining a trap sampling method with CVAAS detection," Talanta, vol. 188, pp. 293-298, 2018.

[20] D. L. F. Da Silva, M. A. P. da Costa, L. O. B. Silva, and W. N. L. dos Santos, "Simultaneous determination of mercury and selenium in fish by CVG AFS," Food Chemistry, vol. 273, pp. 24-30, 2019.

[21] S. S. Lins, C. F. Virgens, W. N. L. dos Santos et al., "On-line solid phase extraction system using an ion imprinted polymer based on dithizone chelating for selective preconcentration and determination of mercury(II) in natural waters by CV AFS," Microchemical Journal, vol. 150, p. 104075, 2019.

[22] X. Yuan, K. Li, Y. Zhang et al., "Point discharge microplasma for the determination of mercury in Traditional Chinese Medicines by chemical vapor generation atomic emission spectrometry," Microchemical Journal, vol. 155, p. 104695 , 2020.

[23] A. Fashi, M. R. Yaftian, and A. Zamani, "Electromembrane extraction-preconcentration followed by microvolume UVVis spectrophotometric determination of mercury in water and fish samples," Food Chemistry, vol. 221, pp. 714-720, 2017.

[24] A. Agarwal, A. K. Verma, M. Yoshida, R. M. Naik, and S. Prasad, "A novel catalytic kinetic method for the determination of mercury(II) in water samples," RSC Advances, vol. 10, no. 42, pp. 25100-25106, 2020.

[25] A. Mandil, L. Idrissi, and A. Amine, "Stripping voltammetric determination of mercury(II) and lead(II) using screenprinted electrodes modified with gold films, and metal ion preconcentration with thiol-modified magnetic particles," Microchimica Acta, vol. 170, no. 3-4, pp. 299-305, 2010.
[26] D. Martín-Yerga, M. B. González-García, and A. CostaGarcía, "Electrochemical determination of mercury: a review," Talanta, vol. 116, pp. 1091-1104, 2013.

[27] F. Okçu, H. Ertaş, and F. N. Ertaş, "Determination of mercury in table salt samples by on-line medium exchange anodic stripping voltammetry," Talanta, vol. 75 , no. 2, pp. 442-446, 2008.

[28] J. Sánchez, E. Castillo, P. Corredor, and J. Ágreda, "Determination of mercury by anodic stripping voltammetry in aqua regia extracts," Portugaliae Electrochimica Acta, vol. 29, no. 3, pp. 197-210, 2011

[29] H. Xiao, W. Wang, S. Pi, Y. Cheng, and Q. Xie, "Anodic stripping voltammetry analysis of mercury(II) on a pyridineAu/pyridine/glassy carbon electrode," Sensors and Actuators B: Chemical, vol. 317, p. 128202, 2020.

[30] Y. Xu, "Oligonucleotide functionalized microporous gold electrode for the selective and sensitive determination of mercury by differential pulse adsorptive stripping voltammetry (DPAdSV)," Analytical Letters, vol. 52, pp. 1-13, 2019.

[31] O. Abollino, A. Giacomino, M. Malandrino, S. Marro, and E. Mentasti, "Voltammetric determination of methylmercury and inorganic mercury with an home made gold nanoparticle electrode," Journal of Applied Electrochemistry, vol. 39, no. 11, pp. 2209-2216, 2009.

[32] Y. Bonfil, M. Brand, and E. Kirowa-Eisner, "Trace determination of mercury by anodic stripping voltammetry at the rotating gold electrode," Analytica Chimica Acta, vol. 424, no. 1, pp. 65-76, 2000.

[33] V. Franke, "Differential pulse anodic stripping voltammetry for mercury determination," Acta Chemica Iasi, vol. 23, 2015.

[34] A. Giacomino, O. Abollino, M. Malandrino, and E. Mentasti, "Parameters affecting the determination of mercury by anodic stripping voltammetry using a gold electrode," Talanta, vol. 75, no. 1, pp. 266-273, 2008.

[35] A. Karthika, V. Ramasamy Raja, P. Karuppasamy, A. Suganthi, and M. Rajarajan, "Electrochemical behaviour and voltammetric determination of mercury (II) ion in cupric oxide/poly vinyl alcohol nanocomposite modified glassy carbon electrode," Microchemical Journal, vol. 145, pp. 737744, 2019.

[36] L. Li, Y. Qiu, Y. Feng, Y. Li, K. Wu, and L. Zhu, "Stripping voltammetric analysis of mercury ions at nitrogen-doped reduced graphene oxide modified electrode," Journal of Electroanalytical Chemistry, vol. 865, p. 114121, 2020.

[37] L. Xiao, W. Dietze, F. Nyasulu, and B. A. F. Mibeck, "Ultramicroband array electrode. 1. Analysis of mercury in contaminated soils and flue gas exposed samples using a goldplated Iridium portable system by anodic stripping voltammetry," Analytical Chemistry, vol. 78, no. 14, pp. 5172-5178, 2006.

[38] A. Moutcine and A. Chtaini, "Electrochemical determination of trace mercury in water sample using EDTA-CPE modified electrode," Sensing and Bio-Sensing Research, vol. 17, pp. 30-35, 2018.

[39] H. R. Akbari Hasanjani and K. Zarei, "An electrochemical sensor for attomolar determination of mercury(II) using DNA/poly-L-methionine-gold nanoparticles/pencil graphite electrode," Biosensors and Bioelectronics, vol. 128, pp. 1-8, 2019.

[40] C. Raril and J. G. Manjunatha, "Fabrication of novel polymermodified graphene-based electrochemical sensor for the determination of mercury and lead ions in water and biological samples," Journal of Analytical Science and Technology, vol. 11, no. 1, p. 3, 2020. 
[41] I. T. Somé, A. K. Sakira, D. Mertens, S. N. Ronkart, and J.-M. Kauffmann, "Determination of groundwater mercury (II) content using a disposable gold modified screen printed carbon electrode," Talanta, vol. 152, pp. 335-340, 2016.

[42] N. Esmaeili, J. Rakhtshah, E. Kolvari, and H. Shirkhanloo, "Ultrasound assisted-dispersive-modification solid-phase extraction using task-specific ionic liquid immobilized on multiwall carbon nanotubes for speciation and determination mercury in water samples," Microchemical Journal, vol. 154, Article ID 104632, 2020.

[43] L. Huson, "Statistical methods for the analysis of repeated measurements," Journal of the Royal Statistical Society: Series D (The Statistician), vol. 52, no. 4, pp. 691-692, 2003.

[44] Princeton Applied Research, "Evaluation of analytical pulse polarography," Analytical Chemistry, vol. 48, no. 2, p. 129A, 1976.

[45] J. S. Ko, M. B. Sassin, J. F. Parker, D. R. Rolison, and J. W. Long, "Combining battery-like and pseudocapacitive charge storage in 3D MnOx@carbon electrode architectures for zinc-ion cells," Sustainable Energy \& Fuels, vol. 2, no. 3, pp. 626-636, 2018.

[46] Á. Lavín, J. Vicente, M. Holgado et al., "On the determination of uncertainty and limit of detection in label-free biosensors," Sensors, vol. 18, no. 7, p. 2038, 2018. 